\title{
The occurrence of myxomycetes on different decay stages of trunks of Picea abies, Pinus sylvestris and Betula spp. in a small oldgrowth forest in southern Finland
}

\author{
TARJA UKKOLA
}

\begin{abstract}
UKKOLA, T. 2002: The occurrence of myxomycetes on different decay stages of trunks of Picea abies, Pinus sylvestris and Betula spp. in a small oldgrowth forest in southern Finland. - Karstenia 42: 13-22. Helsinki. ISSN 0453-3402.

The occurrence of myxomycetes was studied on fallen trunks of Picea abies, Pinus sylvestris, and Betula spp. (B. pendula and B. pubescens) in a small oldgrowth forest in southern Finland in May 1998 - September 1999. The study site is located in Luukkaa Recreation Area, and was left in pristine state in 1966. The sample trunks were chosen to represent different stages of decomposition and checked every second or fourth week in all for 17 times. A total of 325 myxomycete specimens representing 44 taxa in 16 genera were observed. Four taxa, Comatricha pulchella var. fusca, Lycogala exiguum, Licea cf. pusilla, and Physarum bethelii are new records to Finland. During the study, myxomycetes were most abundant on decomposing trunks of Betula spp. (123 specimens), especially on well-decayed trunks. The species diversity was about the same on all studied tree species: 27 taxa were recorded on $P$. abies and P. sylvestris, and 22 on Betula spp. The largest diversity was on two pine trunks with fairly soft wood (a total of 19 taxa). The common myxomycetes, Ceratiomyxa fruticulosa and Lycogala epidendrum, represent generalists in this study, being abundant and present at nearly all decay stages of all studied tree species. Leocarpus fragilis and Tubifera ferruginosa are examples of species that preferred well-decayed wood, and Stemonitopsis reticulata and $S$. typhina were found only on hard to fairly hard wood. The peak of the number of taxa and abundance of myxomycetes occurred from July through to September.
\end{abstract}

Tarja Ukkola, Sauramatie 7 B, FIN-00950 Helsinki, Finland

\section{Introduction}

A fallen trunk is a temporally changing, heterogenous resource unit, a substrate in a dynamic state (Rayner \& Boddy 1988, Renvall 1995b). The decomposing process of wood usually starts within a living tree, the first invaders being bacteria, ascomycetes and certain pathogenic polypores (Swift 1977, Roll-Hansen \& Roll-Hansen 1979, Rayner \& Boddy 1988, Hallaksela \& Salkinoja-Salonen 1992, Renvall 1995a). There are some suggestions that the colonization of wood by myxomycetes also may occur before the trunks fall down, e.g. through the presence of active myxomonads of lignicolous species within the interstitial spaces of branches of still living trees (Ing 1994). Ostrofsky and Shigo (1981) have isolated Comatricha aequalis Peck from discoloured wood chips of living red maple (Acer rubrum L.).

Soon after the death and fall of the tree it will be inhabited by a variety of saprotrophic fungi, and especially Basidiomycetes, make up the majority of organisms responsible for the wood decay (Swift 1977, Rayner \& Boddy 1988, Renvall 1995a). Myxomycetes are regarded rather as scavengers than decomposers, but some species can produce extracellular amylases and even cel- 
lulase (Ali et al. 1992, Ing 1994). Decomposition changes the structure and chemical conditions of the wood and the water potential increases, which in turn increases the availability of water to organisms growing on the substratum (Dix 1985). Also the nutrient contents of the wood changes during the decay. The trunks become more or less covered with mosses and lichens which, for their part, increase the water-holding capasity of the logs. The species composition of bryophytes, hepatics and lichens also changes in relation to the stage of decay (Söderström 1988, Ing 1994). Some myxomycetes seem to be associated with terrestrial mosses (e.g., Gray \& Alexopoulos 1968, Martin \& Alexopoulos 1969, Stephenson \& Studlar 1985, Nannenga-Bremekamp 1991, Ing 1994, 1999).

The fallen, decomposing trunks provide a diversity of ecological niches for lignicolous myxomycetes in forest ecosystems. Even though dead wood is a common substrate for slime moulds, and it is known that species on slightly decayed wood are different from those on well-decayed wood, there are only a few studies about the succession of myxomycetes on decomposing wood. Elliot and Elliot (1920) observed the succession of fungi and myxomycota for eight years on a large, initially sound oak branch that was blown down. In their study the first myxomycete
(Physarum nutans Pers.) appeared after seven years of observation. According to them the wood was still very hard and dense. The only recent studies were made by Takahashi (1999, 2000b, 2001). He studied myxomycete colonies on decaying wood of Pinus densiflora Siebold \& Zucc. and Quercus acutissima Carruth. in three localities in southwestern Japan, in a pine forest (Pinus densiflora) in Rashomon, and in a subalpine coniferous forest in central Japan.

The purpose of the present study was to document the succession, species diversity and abundance of myxomycetes on fallen Norway spruce (Picea abies (L.) Karst.), Scots pine (Pinus sylvestris L.) and birch (Betula pendula Roth and B. pubescens Ehrh.) trunks representing different stages of decomposition and to make observations about the phenology of the lignicolous species in a southern boreal oldgrowth forest.

\section{Material and methods}

\section{The study area}

The field work was carried out in a small (ca. 200 hectares) oldgrowth forest area in Luukkaa, Espoo in southern Finland in May 1998 - September 1999 (Figs. 1-2). The area is located in the northeastern corner of the Luukkaa Recreation Area $23 \mathrm{~km} \mathrm{NW}$ of the centre of Helsinki, and has been unmanaged by forestry since

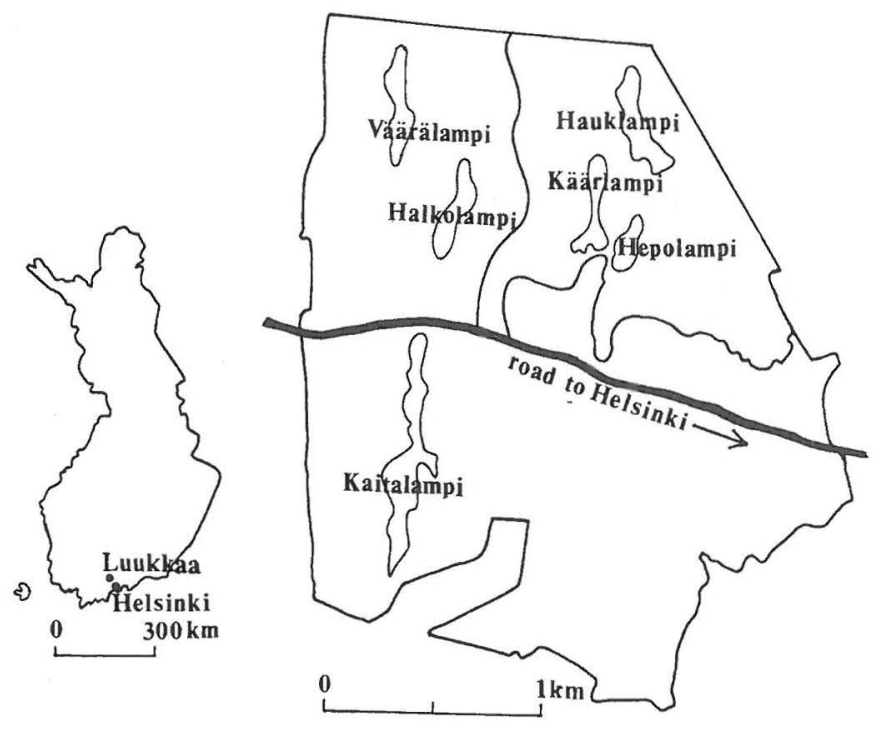

Fig. 1. The location of the research area. The lined area with Hauklampi, Käärlampi and Hepolampi ponds in the northeastern corner of the Luukkaa Recreation Area is the oldgrowth forest where the fallen sample trunks were located. The map is compiled from brochures of Luukkaa and from Anonymous (1988). 
1966. The study area is naturally regenerating southern boreal forest with Picea abies, Pinus sylvestris, and Betula pendula as dominating trees. Because the forest is not very old, the number of natively fallen trees, and especially the number of extensively or almost completely decomposed trunks is not as high as in true oldgrowth forests e.g in northern Finland. The complete decomposition of a large, fallen spruce or pine takes over 100 years in boreal climate (Renvall 1995a). The diameter of the trunk, moisture, and height above the ground affect the speed of decay. Logs lying off the ground (supported by branches or lying on a slope) dry out more easily because of the increased wind and less moist support from the ground below (Söderström 1988).

\section{The sample trunks}

The sample trunks were chosen to represent successive decay stages. They were divided into four different stages of decomposition (Table 1). The decay classification used is according to Renvall (1995a) with some modifications. The main character used in the evaluation of the stage of decay was the hardness of the wood. It was tested by sticking a knife into different parts of the trunk.

A total of 24 fallen trunks of Picea abies, Pinus sylvestris, and Betula spp. (B. pendula and Betula pubescens) were studied, two trunks of each tree species and each decay stage. The diameter of the selected trunks varied from $10 \mathrm{~cm}$ to $27 \mathrm{~cm}$ when measured approximately at the middle of the trunk. The length of the trees varied from a 3.5 metre long block to 20.4 metres. Most of the tree trunks lay totally on the ground, some recently fallen ones were still partly above the ground supported by branches.

\section{Collection of specimens}

The sample trunks were studied with a flashlight twice per month in July - October 1998, and once in May, June, and December 1998, and in April - September 1999. In November 1998 and January - March 1999 the trunks were covered by snow.

When the same species occured on different points of a same trunk on the same observation day, the fructifications were considered as different specimens if they grew at least at the distance of $30 \mathrm{~cm}$ from each other (see Eliasson 1981). When the same species was detected on the same trunk on consecutive collecting times near the previous growing place, it was considered as a separate specimen only if it was fresh and in good condition. Common and easily recognized myxomycete species (mostly Ceratiomyxa fruticulosa (F. Muell.) T. Macbr.) were occasionally identified directly in the field and were not collected for a specimen. The specimens are deposited in the Botanical Museum, University of Helsinki (H).

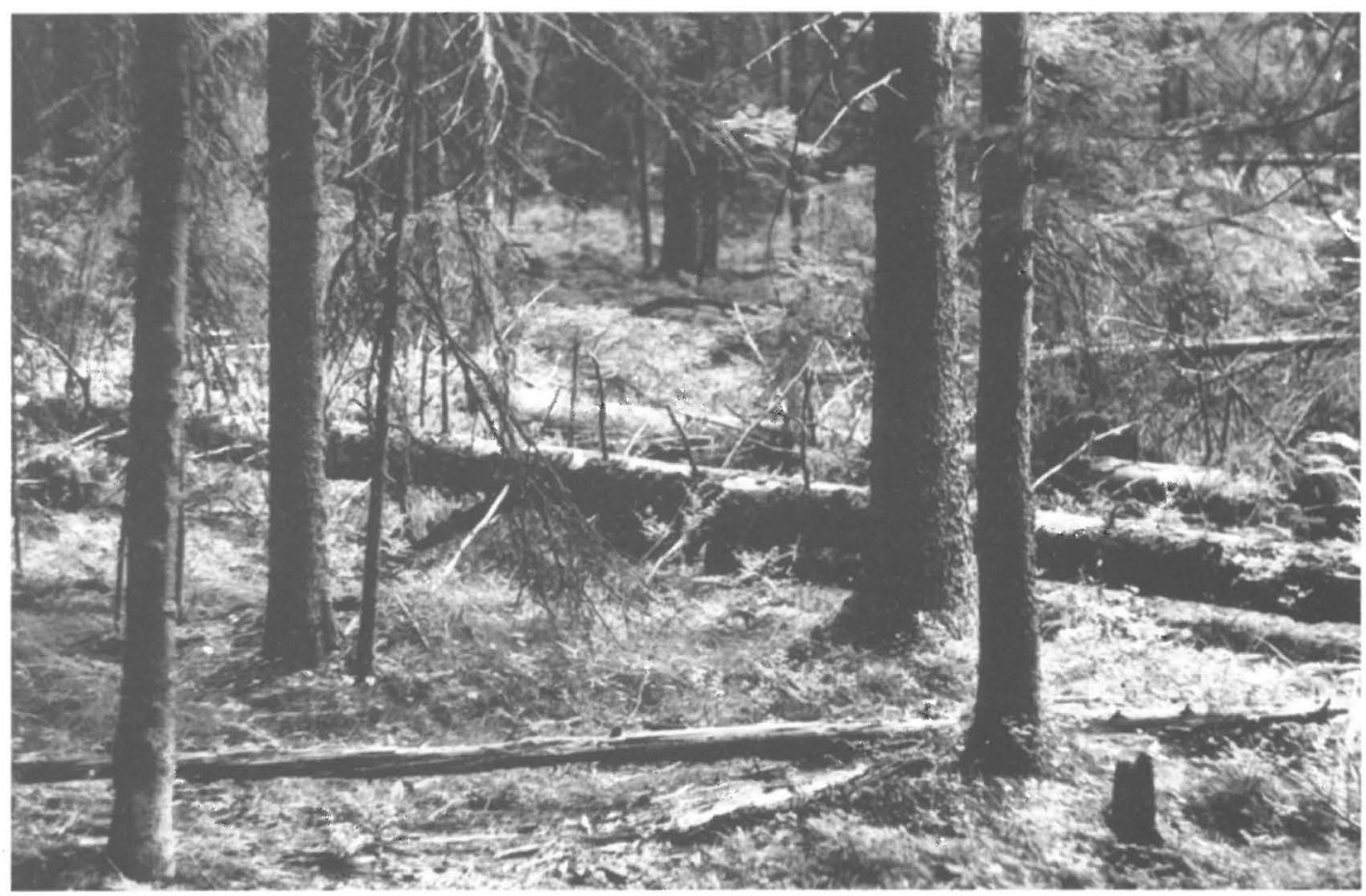

Fig. 2. Boreal spruce forest in the study area of Luukkaa. 
Table 1. The four-point scale used for dividing the sample trunks of Picea abies, Pinus sylvestris, and Betula spp. into different stages of decay in Luukkaa oldgrowth forest area. Decay classification modified from Renvall (1995a).

Decay stage Trunk characters

I Wood hard, pushed knife penetrates only a few mm into the wood. Recently fallen trunks, bark intact or nearly intact. Epiphytic flora chiefly the same as in standing, living trees.

II Wood fairly hard, knife penetrates ca. 1-2 $\mathrm{cm}$ into the wood.

Bark starting to break up or trunk already more or less decorticiated. Epiphytes usually scanty, in patches.

III Wood fairly soft, knife penetrates fairly easily ca. 3-5 cm into the wood; small areas already decomposed, but harder parts exist especially in the upper part of the trunk. Trunks decorticiated or only partly corticiated (except birch). Epiphytic cryptogams fairly abundant on parts of the trunk surface.

IV

Wood soft, partly very soft, the whole blade of the knife easily penetrates into the trunk. Wood extensively decayed and large sections nearly completely decomposed. Usually decorticiated or only small patches of bark left. Trunk covered by bryphytes and lichens, some to many of them typical forest ground inhabitants, occasionaly also covered with some vascular plants.

Table 2. The weather conditions in Luukkaa oldgrowth forest area during the research period. The data is based on the statistics published by the Finnish Meteorological Institute (Helminen et al. 1998a-h, 1999a-g). The nearest weather observation station locates on the airport of Helsinki-Vantaa, ca.18 km from the study area.

\begin{tabular}{|c|c|c|c|c|c|}
\hline \multicolumn{2}{|c|}{$\begin{array}{r}\text { Mean monthly } \\
\text { temperature } \\
\left({ }^{\circ} \mathrm{C}\right)\end{array}$} & \multirow[t]{2}{*}{$\begin{array}{l}\text { Highest temp. } \\
\text { of the month } \\
\left({ }^{\circ} \mathrm{C}\right)\end{array}$} & \multirow[t]{2}{*}{$\begin{array}{l}\text { Lowests temp. } \\
\text { of the month } \\
\left({ }^{\circ} \mathrm{C}\right)\end{array}$} & \multirow[t]{2}{*}{$\begin{array}{r}\text { Rainfall } \\
\mathrm{mm} / \mathrm{month}\end{array}$} & \multirow[t]{2}{*}{$\begin{array}{r}\text { Collecting } \\
\text { date }\end{array}$} \\
\hline 1998 & & & & & \\
\hline May & 10.4 & 23.5 (1 May) & 0.9 (21 May) & 50 & 28 \\
\hline June & 14.4 & 27.1 (15 June) & 4.5 (7 June) & 117 & 20 \\
\hline July & 16.2 & 23.6 (12 July) & 7.1 (5 July) & 125 & 2,21 \\
\hline August & 13.6 & 21.2 (3 Aug.) & 5.6 (28 Aug.) & 107 & 2,19 \\
\hline September & 11.5 & 20.9 (9 Sep.) & 0.2 (30 Sep.) & 49 & 6,26 \\
\hline October & 5.8 & 11.9 (23 Oct.) & -4.4 (7 Oct.) & 135 & 11,24 \\
\hline November & -3.4 & 3.7 (1 Nov.) & -17.2 (21 Nov.) & 33 & - \\
\hline December & -2.2 & 5.0 (19 Dec.) & -15.8 (24 Dec.) & 51 & 5 \\
\hline \multicolumn{6}{|l|}{1999} \\
\hline April & 5.7 & 20.0 (20 Apr.) & -5.4 (5 Apr.) & 55 & 13 \\
\hline May & 8.0 & 21.4 (22 May) & -4.0 (3 May) & 11 & 13 \\
\hline June & 18.4 & 28.1 (26 June) & 3.6 (1 June) & 25 & 27 \\
\hline July & 19.1 & 31.0 (14 July) & 9.3 (5 July) & 25 & 21 \\
\hline August & 15.4 & 29.5 (4 Aug.) & 5.1 (23 Aug.) & 66 & 8 \\
\hline September & 12.8 & 23.8 (5 Sep.) & -0.2 (27 Sep.) & 40 & 5 \\
\hline
\end{tabular}

\section{Weather conditions}

The weather conditions during the research are compiled in Table 2. The year 1998 was a rainy one. On 5 Nov. the first snow came, and the temperature fell below zero. In southern Finland the thickness of the snow was exceptionally high for the time of the year: $15-30 \mathrm{~cm}$ (Helminen et al. 1998g), and the trunks could not be checked. At the end of the month the snow melted and the trunks were checked on 5 Dec. In January - March 1999 the trunks were totally covered by snow and could not be studied until mid April. The summer 1999 was exceptionally dry and sunny, in southern and southwestern Finland the growing season was one of the driest for 50 years (Helminen et al. 1999g), and the trunks were studied only once per month.

\section{Results and discussion}

A total of 325 myxomycete specimens were observed. They belong to 44 taxa in 16 genera (Tables 3-5). Some of the collected specimens (18 out of 325) were in bad condition (e.g. excessivly mouldy) or otherwise puzzling, and could be 
identified only to genus level. These specimens are not included to the lists in Tables 3-5. Four of the taxa, viz. Comatricha pulchella (C. Bab.) Rostaf. var. fusca Lister, Licea cf. pusilla Schrad., Lycogala exiguum Morgan, and Physarum bethelii T. Macbr. are new records for Finland. Of Stemonitis lignicola Nann.-Bremek there is one (unpublished) earlier collection from Finland (Varsinais-Suomi, Kimito, on decayed wood of Pinus sylvestris, 1995 Wikström 5353, H)

Most Licea species are very small and difficult to detect in the field, and all Liceas listed here grew mixed with other myxomycete species and were detected when these other species were examined under microscope in the laboratory. It is probable that Liceas (especially Licea minima Fr.) were more abundant on the sample trunks than the figures given in Tables 3-5 indicate.

The only fallen trunk on which I did not detect any myxomycetes during the whole research was a fairly small, recently fallen trunk of Betula. The whole $\log$ lay on the ground on a blanket of Sphagnum in a wet place. The corresponding recently fallen Betula trunk selected as a second sample tree was a large one, laying partly off the ground because of many strong branches. It produced a great number of myxomycete specimens.

\section{Myxomycetes on different decay stages}

The myxomycete taxa observed on different stages of decay of Picea abies, Pinus sylvestris, and Betula spp. trunks are compiled in Tables 3-5.

Takahashi $(1999,2000 b, 2001)$ reported in his studies in Japan that the species composition of myxomycete changed as the wood (of Quercus acutissima, Pinus densiflora and other conifers) decayed. In my study it is not possible to draw any accurate conclusions from the changes in the species composion in relation to the different stages of decay, since I found only one to few specimens of many myxomycete species during the research period. The summer 1999 was unfavourable for slime moulds, from mid April to early September I found only 58 specimens growing on the studied trunks. The results in Luukkaa oldgrowth forest agree with the known fact that there are species that prefer certain stages of decay, but there are also generalists, common species with a long growing season occurring on different decay stages on conifer and birch trunks.
The most common species in this study was Lycogala epidendrum (L.) Fr. It grew from late May to late October, and was detected on all other studied tree trunks except on Picea abies representing decomposition stage I, and on Betula representing decay stage IV. The only Lycogala species observed growing on the latter was $L$. exiguum. Ceratiomyxa fruticulosa was also common, especially on Pinus sylvestris, and also on Picea abies. It grew on all stages of decomposition on both of the species, but was less abundant on Betula and grew only on trunks representing decay stages III and IV. Takahashi (2000b, 2001) obtained similar results with C. fruticulosa and L. epidendrum in coniferous forests in Japan: they grew on slightly or moderately decayed to strongly decayed wood from May through October, however, dominating in summer. In the dry summer 1999, Lycogala epidendrum was the only common myxomycete growing on the following trunks: Picea abies II-III, Pinus sylvestris I-III, and Betula II-IV.

Didymium melanospermum (Pers.) T. Macbr. occurred on slightly to well-decayed wood on conifer trunks, on birch it was detected only twice on decay stage IV. Trichia botrytis (J. F. Gmel.) Pers. seems not to be specially dependent on the stage of decomposition, most common, however, it occurred on Picea on only slightly decayed wood. Trichia decipiens (Pers.) T. Macbr. preferred decay stage II on conifer trunks, on birch it was common on decay stage IV. The species of the genus Arcyria grew on slightly to moderately decayed wood, no specimens were found on decay stage IV. Leocarpus fragilis (Dicks.) Rostaf. preferred well-decayed wood, as also did Tubifera ferruginosa (Batsch) J. F. Gmel. The latter species was detected only on well-decayed conifer wood.

In Takahashi's $(1999,2000 b, 2001)$ studies only a few taxa of myxomycetes occurred on hard, slightly decayed wood. Schnittler and Novozhilov (1998) obtained similar results when studying late-autumn myxomycetes on bark and decomposing wood in northern Ammergauer Alps (in October). They seldom found slime moulds on slightly decayed wood which, according to them, was due to the absence of most Stemonitales. According to Takahashi $(1999,2000 \mathrm{~b}$, 2001) the species diversity (and colony areas) increased on softer, more decayed wood, but on the softest, significantly decayed wood the number of species again decreased. In this study 
Table 3. Myxomycetes observed on fallen trunks of Picea abies in Luukkaa oldgrowth forest area in May 1998September 1999.

\begin{tabular}{|c|c|c|c|c|c|}
\hline \multirow[b]{2}{*}{ Taxa } & \multicolumn{4}{|c|}{ Stage of decay } & \multirow[b]{2}{*}{$\begin{array}{l}\text { Total number } \\
\text { of specimens }\end{array}$} \\
\hline & I & II & III & IV & \\
\hline Arcyria cinerea & & 2 & & & 2 \\
\hline Arcyria incarnata & 1 & & & & 1 \\
\hline Arcyria nutans & & 1 & 1 & & 2 \\
\hline Arcyria pomiformis & & 1 & & & 1 \\
\hline Ceratiomyxa fruticulosa & 1 & 3 & 2 & 8 & 14 \\
\hline Comatricha ellae & & 1 & & & 1 \\
\hline Cribraria rufa & & 1 & 1 & 1 & 3 \\
\hline Cribraria vulgaris & 1 & & & & 1 \\
\hline Didymium melanospermum & 1 & 2 & 1 & 2 & 6 \\
\hline Enerthenema papillatum & 1 & & & & 1 \\
\hline Fuligo septica & 2 & & & & 2 \\
\hline Leocarpus fragilis & & & & 2 & 2 \\
\hline Licea minima & 1 & 1 & & & 2 \\
\hline Licea variabilis & & & & 1 & 1 \\
\hline Lycogala epidendrum & & 8 & 1 & 3 & 12 \\
\hline Physarum bethelii & & & 1 & & 1 \\
\hline Physarum nutans & & 4 & 5 & & 9 \\
\hline Reticularia intermedia & & 1 & & & 1 \\
\hline Stemonitis axifera & & & & 1 & 1 \\
\hline Stemonitis fusca & & 2 & & & 2 \\
\hline Stemonitis lignicola & & & & 2 & 2 \\
\hline Stemonitis pallida & & & 1 & & 1 \\
\hline Stemonitopsis hyperopta & & & 1 & 2 & 3 \\
\hline Stemonitopsis reticulata & & 1 & & & 1 \\
\hline Trichia botrytis & 6 & 2 & 1 & 1 & 10 \\
\hline Trichia decipiens & & 3 & & & 3 \\
\hline Tubifera ferruginosa & & & & 2 & 2 \\
\hline
\end{tabular}

Table 4. Myxomycetes observed on fallen trunks of Pinus sylvestris in Luukkaa oldgrowth forest area in May 1998September 1999.

\begin{tabular}{|c|c|c|c|c|c|}
\hline \multirow[b]{2}{*}{ Taxa } & \multicolumn{4}{|c|}{ Stage of decay } & \multirow[b]{2}{*}{$\begin{array}{l}\text { Total number } \\
\text { of specimens }\end{array}$} \\
\hline & I & II & III & IV & \\
\hline Arcyria cinerea & & & 1 & & 1 \\
\hline Arcyria incarnata & 3 & 1 & 1 & & 5 \\
\hline Arcyria nutans & & 2 & & & 2 \\
\hline Arcyria pomiformis & 1 & & 1 & & 2 \\
\hline Ceratiomyxa fruticulosa & 2 & 8 & 8 & 4 & 22 \\
\hline Comatricha elegans & & & 1 & & 1 \\
\hline Comatricha nigra & 3 & & 1 & 1 & 5 \\
\hline C. pulchella var. fusca & & & 2 & & 2 \\
\hline Cribraria personi & & & & 1 & 1 \\
\hline Cribraria rufa & & & 1 & & 1 \\
\hline Didymium melanospermum & 1 & 2 & 3 & & 6 \\
\hline Didymium nigripes & & & & 1 & 1 \\
\hline Enerthenema papillatum & 2 & & 1 & & 3 \\
\hline Fuligo septica & 1 & & 1 & 1 & 3 \\
\hline Leocarpus fragilis & & & & 2 & 2 \\
\hline
\end{tabular}


Lepidoderma tigrinum

Licea minima

Licea cf. pusilla

Lycogala epidendrum

Physarum nutans

Reticularia intermedia

Stemonitis lignicola

Stemonitis virginiensis

Stemonitopsis reticulata

Trichia botrytis

Trichia decipiens

Tubifera ferruginosa

$\begin{array}{rrrrr} & & 2 & 2 & 4 \\ 3 & 2 & 2 & & 5 \\ & 5 & 3 & & 3 \\ & & 1 & 5 & 14 \\ & & 3 & & 3 \\ & & 1 & & 1 \\ 1 & 1 & & & 2 \\ & 2 & & & 3 \\ & 1 & 2 & & 3 \\ & 6 & & 3 & 3\end{array}$

Table 5. Myxomycetes observed on fallen trunks of Betula spp. in Luukkaa oldgrowth forest area in May 1998September 1999

\begin{tabular}{|c|c|c|c|c|c|}
\hline \multirow[b]{2}{*}{ Taxa } & \multicolumn{4}{|c|}{ Stage of decay } & \multirow[b]{2}{*}{$\begin{array}{l}\text { Total number } \\
\text { of specimens }\end{array}$} \\
\hline & I & II & III & IV & \\
\hline Arcyria affinis & 3 & 1 & & & 4 \\
\hline Arcyria nutans & & 1 & 1 & & 2 \\
\hline Ceratiomyxa fruticulosa & & & 1 & 5 & 6 \\
\hline Comatricha elegans & & & & 1 & 1 \\
\hline Comatricha nigra & & & & 1 & 1 \\
\hline Didymium melanospermum & & & & 2 & 2 \\
\hline Leocarpus fragilis & & 1 & 3 & 11 & 15 \\
\hline Licea minima & & & & 2 & 2 \\
\hline Lycogala exiguum & & & & 3 & 3 \\
\hline Lycogala epidendrum & 4 & 8 & 5 & & 17 \\
\hline Physarum cinereum & 2 & & & & 2 \\
\hline Physarum leucophaeum & 1 & & 1 & & 2 \\
\hline Physarum leucopus & 4 & & 1 & & 5 \\
\hline Physarum nutans & 4 & & 3 & 3 & 10 \\
\hline Reticularia lycoperdon & & 1 & & & 1 \\
\hline Stemonitis axifera & & & 3 & 3 & 6 \\
\hline Stemonitopsis typhina & 6 & & & & 6 \\
\hline Trichia botrytis & & 1 & & 2 & 3 \\
\hline Trichia decipiens & & & 2 & 15 & 17 \\
\hline Trichia favoginea & & 1 & & & 1 \\
\hline Trichia scabra & 3 & & & 2 & 5 \\
\hline Trichia varia & & & 2 & 2 & 4 \\
\hline
\end{tabular}

I had similar results only on pine trunks, but one must take account that the softest, almost completely decomposed trunks were not yet existing in Luukkaa.

The increasing of decay increases the water potential of wood and the amount of mosses and lichens growing on the trunks which, for their part, increase the water-holding capacity and reduce evaporation (Dix 1985, Renvall 1995b). That is why one would expect that the most productive trunks in the dry summer 1999 would have been the softest, most decayed logs. This was seen only on birch trunks, on spruce and pine the total number of collections during June-September 1999 was highest on decay stage II.

\section{Myxomycetes on different decay stages of different tree species}

On the eight decomposing trunks of Picea abies studied, I discovered a total of 93 specimens representing 27 species (Table 3). Four specimens were identified only to genus level and are not included in Table 3. The Picea trunks representing 
decay stage II produced the most myxomycetes on spruce. Also the number of different species was highest on this stage of decomposition, but not considerably higher than on stages III and IV. Ceratiomyxa fruticulosa was common and grew on all stages of decay, as also did Trichia botrytis. Lycogala epidendrum was also common on spruce, it grew on decay stages II to IV, being most common on decay stage II. Didymium melanospermum and Physarum nutans were fairly common on spruce trunks. The first one grew on all stages of decay, the second on stages II and III.

The trunks of Pinus sylvestris produced a total of 109 specimens and 27 species (five specimens were identified only to genus level) (Table 4). Myxomycetes were most abundant on trunks with fairly soft wood (decay stage III). The number of different species was also highest on this decay stage. Fallen pine trunks with fairly hard wood (decay stage II) produced nearly as many specimens, but the species diversity was lower. Ceratiomyxa fruticulosa was the commonest species on fallen pine trunks, and it grew on all stages of decomposition, being, however, most common on decay stages II and III. Lycogala epidendrum was common and was observed on all stages of decay. Fairly common species on pine were Arcyria incarnata (Pers.) Pers. (grew on decay stages I-III), Comatricha nigra (Pers.) Schroet. (on decay stages I, III, IV), Didymium melanospermum (on decay stages I-III), Licea minima (on decay stages I-III), and Trichia decipiens (only on decay stage II). Lepidoderma tigrinum (Schrad.) Rostaf. grew on fairly soft (decay stage III) to soft (decay stage IV) logs covered by mosses.

A total of 123 specimens and 22 species were observed on fallen trunks of Betula spp. (nine specimens were identified only to genus level) (Table 5). Trunks representing decay stage IV produced the most specimens and the most species on birch. The species diversity, however, was not much lower on decay stage III. Common species on birch were Lycogala epidendrum (grew on decay stages I-III), Leocarpus fragilis (II-IV, mostly on IV), Physarum nutans (I, III, IV), and Trichia decipiens (III-IV, mostly on IV). Ceratiomyxa fruticulosa was less common than on spruce and pine trunks, and it grew only on decay stages III and IV. Stemonitopsis typhina (F. H. Wigg.) Nann.-Bremek. is usually considered to prefer more decayed wood (see Ing 1994), but in this study it was detected only on recently fallen birch trunk (decay stage I).

On Betula trunks there were more Physarum and Trichia species than on conifer logs. All Cribraria species observed grew on spruce and pine, as also Tubifera ferruginosa, which was collected only from well-decayed trunks.

\section{Phenology}

In Luukkaa oldgrowth forest area on spruce trunks the slime moulds were most abundant and the species diversity was highest in July (22 specimens and 11 species) and August (29 specimens and 18 species). On pine trunks the most productive months were July (28 specimens and 12 species), August (28 specimens and 12 species), and September (27 specimens and 17 species). Even though the peak of the abundence of myxomycetes on birch trunks also occurred in July (27 specimens and 14 species) and September ( 35 specimens and 13 species), the peak was not as sharp as it was on spruce and pine. On birch the abundance and species diversity of myxomycetes distributed more evenly between different months. For some reason in this study, August was a less favourable month for myxomycetes on birch trunks (15 specimens and 7 species) than it was on spruce and pine.

According to Ing (1994) the myxomycete species are seasonal, but the seasonality of a species may vary in different climatic zones. In the boreal forest of Luukkaa Comatricha nigra, Leocarpus fragilis, Licea minima, Lycogala epidendrum, Trichia botrytis, and T. decipiens were observed from spring to late autumn; L. minima (on pine II), T. botrytis (on spruce I), and $T$. decipiens (on birch IV) even on early December when there was a thin snow cover on the ground and the temperature was minus $3.8^{\circ} \mathrm{C}$. On the same day also Stemonitopsis reticulata (H. C. Gilbert) Nann.-Bremek. \& Y. Yamam. was collected (from pine II). In Stephensson's (1988) study in southwestern Virginia only a few species could be collected during the whole field season: e.g. L. epidendrum and Stemonitopsis typhina grew from May through October. Also Eliasson (1981) and Takahashi (2000b) reported that L. epidendrum occurs from May to October (in a spruce forest in south Sweden and in a pine forest in Japan), and Hamashima (1964) noted that the growing season of the genus Lycogala was long on shiitake- 
cultivating wood-logs in Aichi Prefecture in Japan. In Luukkaa oldgrowth forest $S$. typhina occurred from mid May to mid October, but was not observed in June and July. Eliasson (1981) reported that in a spruce forest in southern Sweden Trichia botrytis and $T$. decipiens were restricted to autumn, they were observed in SeptemberOctober, as also, at least mainly, Leocarpus fragilis and Didymium melanospermum. All of these species were observed also in the spring and summer in this study, being, however, more abundant in the autumn, especially the three first mentioned species. Cribraria rufa (Roth) Rostaf., was collected already in May, but the next specimens were not observed until September and October. Ceratiomyxa fruticulosa was collected from late May through August and Trichia scabra Rostaf. from mid April to early September. The occurrense of Lepidoderma tigrinum (only on pine) emphasised on spring, one collection originates from late September.

Most of the other observed taxa usually grew from July through September. When all observations of all trunks and all stages of decomposition are counted, the clear peak time for seasonal appearance of fruiting bodies, and highest number of different taxa occurred during these three months. In Stephenson's (1989) study in Virginia the highest monthly totals for both the number of collections and the number of different species were recorded for July and August. In a study in sub-alpine forest in the southern Alps in central Japan the total number of collected species was highest in August, but not considerably higher than in September and October (Takahashi 2000a). In the same study the number of total collections was clearly highest in September. Hamashima (1964) obtained similar results from Aichi Prefecture, Japan: the seasonal peak time of myxomycete fructifications occurred from July to early September.

\section{Taxonomy}

The three Licea specimens determined here as Licea cf. pusilla were detected on consecutive collecting times on a trunk of Pinus sylvestris representing decay stage III. One of the specimen (TU 838A) seems to be a typical Licea pusilla with olive-brown, densely warted, (13-)13.515.0-16(-17) $\mu \mathrm{m}$ large spores. In two other specimens (TU 797B and 819B) the spores are slight- ly lighter, 12-13.4-14 $\mu \mathrm{m}$ in diameter. The spore size of $L$. pusilla is usually $15-17 \mu \mathrm{m}$, but varies from 13 to $20 \mu \mathrm{m}$ (Martin \& Alexopoulos 1969, Nannenga-Bremekamp 1991, Neubert et al. 1993, Ing 1999). The author has earlier studied the lectotype of Licea pusilla Schrad. var. pygmaea Meyl. (Switzerland, Canton Vaud, La Gittaz, Oct. 1930, Meylan, LAU). The spore colour and ornamentation in that specimen is the same as in specimens $T U 797 B$ and $819 B$, but the spores are slightly smaller, $11.0-11.5-12(-13) \mu \mathrm{m}$. Since all three Licea specimens grew on the same trunk and were discovered on consecutive collecting times, I decided to put them all under the name Licea cf. pusilla.

One of the five Trichia scabra specimens (TU 885), reported here has somewhat atypical capillitial threads. The spiral ornamentation of the elaters is coarse, and the spines are up to $2 \mu \mathrm{m}$ tall. All other characters fit to T. scabra.

Trichia favoginea (Batsch) Pers. in this paper was recognized following Farr (1958). In the only specimen found the spore ornamentation is as if intermediate of typical T. favoginea and T. persimilis P. Karst., and the 4.5-5 $\mu \mathrm{m}$ thick elaters are spiny.

Acknowledgements: I wish to thank the curator of BPI (U.S. National Fungus Collections, Beltsville, Maryland) for the loans of specimens, and Dr. Kazunari Takahashi and Mr. David W. Mitchell for their valuable comments of the manuscript.

\section{References}

Anonymous, 1988: Helsingin kaupungin ulkoilualueiden arvokkaat luontokohteet Espoossa. Hoito- ja käyttösuunnitelmat 1988-2008. - Helsingin kaupungin kiinteistövirasto, Metsä- ja maatalousosasto. $237 \mathrm{pp}$. Ali, N.M., Das, R. M. \& Kalyanasundaram, I. 1992: Extracellular amylase in myxomycete plasmodia and its fate during differentation. - Mycol Res. 96: 990992.

Dix, N. J. 1985: Changes in relationships between water content and water potential after decay and its significance for fungal succession. - Trans. British Mycol. Soc. 85: 649-653.

Eliasson, U. 1981: Patterns of occurrence of myxomycetes in a spruce forest in south Sweden. - Holarct. Ecol. 4: 20-31.

Elliot, W. T. \& Elliot, J. S. 1920: The sequence of fungi and mycetozoa. - J. Bot. London 58: 273-274.

Farr, M. L. 1958: Taxonomic studies in the Myxomycetes. I. The Trichia favoginea complex. - Mycologia 50: $357-369$.

Gray, W. D. \& Alexopoulos, C. J. 1968: Biology of the Myxomycetes. - Ronald Press, New York. 288 pp. 
Hallaksela, A.-M. \& Salkinoja-Salonen, M. 1992: Bacteria inhabiting artificially inoculated xylem of Picea abies. - Scand. J. Forest Res. 7: 165-175.

Hamashima, S. 1964: Seasonal aspects of slime moulds on shiitake-cultivating wood logs. - J. Japanese Bot. 39: 189-192.

Helminen, J., Nordlund, A. \& Karlsson, P. (eds.) 1998a: Ilmastokatsaus 05/1998. - Ilmatieteen laitos (Finnish Meteorological Institute).

Helminen, J., Nordlund, A. \& Karlsson, P. (eds.) 1998b: Ilmastokatsaus 06/1998. - Ilmatieteen laitos (Finnish Meteorological Institute).

Helminen, J., Nordlund, A. \& Karlsson, P. (eds.) 1998c: Ilmastokatsaus 07/1998. - Ilmatieteen laitos (Finnish Meteorological Institute).

Helminen, J., Nordlund, A. \& Karlsson, P. (eds.) 1998d: Ilmastokatsaus 08/1998. - Ilmatieteen laitos (Finnish Meteorological Institute).

Helminen, J., Nordlund, A. \& Karlsson, P. (eds.) 1998e: Ilmastokatsaus 09/1998. - Ilmatieteen laitos (Finnish Meteorological Institute).

Helminen, J., Nordlund, A. \& Karlsson, P. (eds.) 1998f: Ilmastokatsaus 10/1998. - Ilmatieteen laitos (Finnish Meteorological Institute).

Helminen, J., Nordlund, A. \& Karlsson, P. (eds.) 1998g: Ilmastokatsaus 11/1998. - Ilmatieteen laitos (Finnish Meteorological Institute).

Helminen, J., Nordlund, A. \& Karlsson, P. (eds.) 1998h: Ilmastokatsaus 12/1998. - Ilmatieteen laitos (Finnish Meteorological Institute).

Helminen, J., Nordlund, A. \& Karlsson, P. (eds.) 1999a: Ilmastokatsaus 04/1999. - Ilmatieteen laitos (Finnish Meteorological Institute).

Helminen, J., Nordlund, A. \& Karlsson, P. (eds.) 1999b: Ilmastokatsaus 05/1999. - Ilmatieteen laitos (Finnish Meteorological Institute).

Helminen, J., Nordlund, A. \& Karlsson, P. (eds.) 1999c: Ilmastokatsaus 06/1999. - Ilmatieteen laitos (Finnish Meteorological Institute).

Helminen, J., Nordlund, A. \& Karlsson, P. (eds.) 1999d: Ilmastokatsaus 07/1999. - Ilmatieteen laitos (Finnish Meteorological Institute).

Helminen, J., Nordlund, A. \& Karlsson, P. (eds.) 1999e: Ilmastokatsaus 08/1999. - Ilmatieteen laitos (Finnish Meteorological Institute).

Helminen, J., Nordlund, A. \& Karlsson, P. (eds.) 1999f: Ilmastokatsaus 09/1999. - Ilmatieteen laitos (Finnish Meteorological Institute).

Helminen, J., Nordlund, A. \& Karlsson, P. (eds.) 1999g: Ilmastokatsaus 12/1999. - Ilmatieteen laitos (Finnish Meteorological Institute).

Ing, B. 1994: The phytosociology of myxomycetes. New Phytol. 126: 175-201.

Ing, B. 1999: The myxomycetes of Britain and Ireland. An identification handbook. - The Richmond Publishing Co. Ltd., Slough. 374 pp.

Martin, G. W. \& Alexopoulos, C. J. 1969: The Myxomycetes. - Univ. Iowa Press, Iowa City. 560 pp.

Nannenga-Bremekamp, N. E. 1991: A guide to temperate myxomycetes. - Biopress, Bristol. 409 pp. (Engl. transl. by A. Feest and Y. Burggraaf of De Nederlandse Myxomyceten. 1974. Kon. Nederlandse Nat. Ver., Zutphen. 440 pp. )

Neubert, H., Nowotny, W. \& Baumann K. 1993: Die Myxomyceten Deutschlands und des angrenzenden Alpenraumes unter besonderer Berücksichtigung Österreichs 1. Ceratiomyxales, Echinosteliales, Liceales, Trichiales. - Karlheinz Baumann Verlag, Gomaringen. 343 pp.

Ostrofsky, A. \& Shigo, A. 1981: A myxomycete isolated from discolored wood of living red maple. - Mycologia 73: 997-1000.

Rayner, A. D. M. \& Boddy, L. 1988: Fungal decomposition of wood: its biology and ecology. - John Wiley \& Sons, Bath. 587 pp.

Renvall. P. 1995a: Community structure and dynamics of wood-rotting Basidiomycetes on decomposing conifer trunks in northern Finland. - Karstenia 35: 151.

Renvall, P. 1995b: Communities of wood-rotting Basidiomycetes on decomposing conifer trunks in northern Finland - new species and temporal dynamics. Publ. Bot. Univ. Helsinki 20: 1-14. Ph.D. thesis.

Roll-Hansen, F. \& Roll-Hansen, H. 1979: Microflora of sound-looking wood in Picea abies stems. - European J. Forest Pathol. 9: 308-316.

Schnittler, M. \& Novozhilov, Y. K. 1998: Late-autumn myxomycetes of the northern Ammergauer Alps. Nova Hedwigia 66: 205-222.

Stephenson, S. L. 1988: Distribution and ecology of Myxomycetes in temperate forests. I. Patterns of occurrence in the upland forests of southwestern Virginia. - Canad. J. Bot. 66: 2187-2207.

Stephenson, S. L. \& Studlar, M. S. 1985: Myxomycetes fruiting upon bryophytes: coincidence or preference. - J. Bryol. 13: 537-548.

Swift, M. J. 1977: The ecology of wood decomposition. - Sci. Prog. Oxford 64: 179-203.

Söderström, L. 1988: Sequence of bryophytes and lichens in relation to substrate variables of decaying coniferous wood in northern Sweden. - Nordic J. Bot. 8: 89-97.

Takahashi, K. 1999: Occurrence of myxomycetes in relation to the decaying state of Pinus densiflora and Quercus acutissima. - Bull. Okayama Pref. Nature Conservation Center 7: 53-60.

Takahashi, K. 2000a: Seasonal changes and preference of substrata on occurrence of Myxomycetes in subalpine forest of the southern Alps in central Japan. The Asahi Bulletin 21: 35-42.

Takahashi, K. 2000b: Ecology of myxomycetes in relation to the decaying state of Pinus densiflora in Rashomon, Okayama Prefecture. - Bull. Okayama Pref. Nature Conservation Center 8: 33-1.

Takahashi, K. 2001: Occurrence of lignicolous Myxomycetes and their assosiation with the decaying state of coniferous wood in sub-alpine forests of central Japan. - The Asahi Bulletin 22: 1-5. 